\title{
JURISDIÇÃO CONSTITUCIONAL \\ E A QUESTÃO DO ABORTO \\ A PARTIR DO HC 124.306/RJ
}

\author{
TÁSSIA APARECIDA GERVASONI ${ }^{\dagger}$ \\ FELIPE DA VEIGA DIAS ${ }^{\dagger \dagger}$
}

\begin{abstract}
RESUMO: Este estudo investigará a atuação do Supremo Tribunal Federal no julgamento do Habeas Corpus 124.306/RJ, buscando identificar, a partir da análise jurisprudencial, os parâmetros da decisão e o que esse julgamento revela sobre o exercício da jurisdição constitucional pela Corte. Para tanto, empregar-se-á uma metodologia de abordagem indutiva, um método de procedimento monográfico e a técnica de pesquisa por documentação indireta. A pesquisa desenvolvese em três momentos, partindo de (1) um exame detalhado do Habeas Corpus 124.306/RJ, nas perspectivas formal e (2) material da decisão, para (3) um estudo crítico sobre o exercício da jurisdição constitucional e sobre o que as decisões analisadas revelam em termos de comportamento dos ministros enquanto membros de uma Corte Constitucional. Dentre as principais conclusões da pesquisa, destaca-se o protagonismo dos ministros em prejuízo das competências constitucionais destinadas ao plenário do Tribunal, o que constitui ameaça à efetividade do texto constitucional e à própria democracia.
\end{abstract}

PalavRAS-ChAVE: HC 124.306/RJ; Aborto; Jurisdição Constitucional;

\footnotetext{
${ }^{\dagger}$ Doutora em Direito pela Universidade do Vale do Rio dos Sinos (UNISINOS), com período sanduíche junto à Universidad de Sevilla, Espanha, Mestre e Bacharel em Direito pela Universidade de Santa Cruz do Sul (UNISC), Coordenadora da PósGraduação em Direito lato sensu da Faculdade Meridional (IMED), Pesquisadora do Grupo de Pesquisa Estado e Constituição e Advogada.

† Doutor, com período sanduíche na Universidade de Sevilla, Espanha, e Mestre em Direito pela UNISC, Pós-Graduação em Direitos Fundamentais e Constitucionalização do Direito pela Pontifícia Universidade Católica do Rio Grande do Sul (PUC-RS), Professor da Faculdade Meridional (IMED) e Advogado.
} 
Supremo Tribunal Federal (STF).

\begin{abstract}
This study will investigate the action of the Brazilian Supreme Court in the judgment of Habeas Corpus 124.306/RJ, seeking to identify, from the jurisprudential analysis, the parameters of its decision and what this judgment reveals about the exercise of judicial review by the Court. Thus, it will be used an inductive methodological approach, a monographic procedure method and a research technique of indirect documentation. The research is developed in three moments, starting with (1) a detailed examination of the Habeas Corpus 124,306/RJ, from the formal and (2) material perspectives of the decision, to (3) a critical study on the exercise of judicial review and concerned to what the analyzed decisions reveal relating to the behavior of Justices as members of a Constitutional Court. Among the main results of the research, it is possible to highlight the Justices' actuation to the detriment of constitutional competencies assigned to the plenary of the Court, which constitutes a threat to the effectiveness of the constitutional text and to democracy itself.
\end{abstract}

KEYWORDS: HC 124.306/RJ; Abortion; Judicial Review; Brazilian Supreme Court. 


\section{SUMÁRIO:}

I. INTRODUÇÃO ..............................................................................................1283

II. ANÁliSE DO HABEAS CORPUS 124.306/RJ A PARTIR DO POSICIONAMENTO DO MINISTRO LUÍS ROBERTO BARROSO.........1285

III. A APRECIAÇÃO DO MÉRITO DO HABEAS CORPUS 124.306/RJ......1294

IV. O HABEAS CORPUS 124.306/RJ E O QUE O SEU JULGAMENTO REPRESENTA EM TEMOS DE ATUAÇÃO DA JURISDIÇÃO CONSTITUCIONAL.................................................1300

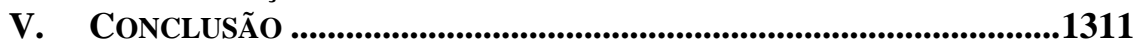

VI. REFERÊNCIAS...........................................................................................1312

TABLE OF CONTENTS:

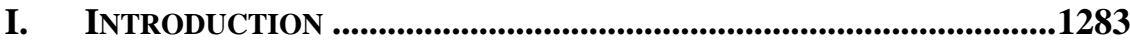

II. ANALYZING THE HABEAS CORPUS 124.306/RJ FROM

JUSTICE MINISTRO LUÍS ROBERTO BARROSO'S POSITIONING ....1285

III. APPRECIATING THE MERITUM OF HABEAS CORPUS 124.306/RJ..1294

IV. THE HABEAS CORPUS 124.306/RJ AND WHAT ITS JUDGMENT REPRESENTS TO JUDICIAL REVIEW ...1300

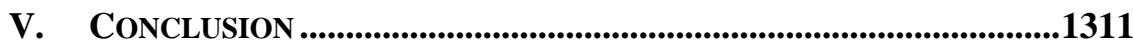

VI. REFERENCES ….............................................................................................1312 


\section{INTRODUÇÃO}

Ao apagar das luzes do ano de 2016, a Primeira Turma do Supremo Tribunal Federal proferiu decisão que ainda renderia muita discussão para o ano seguinte. Por ocasião do julgamento do Habeas Corpus 124.306/RJ, sobretudo a partir do voto-vista do Ministro Luís Roberto Barroso, pautou-se a inconstitucionalidade material da criminalização do aborto realizado até o terceiro trimestre de gestação, em razão da violação de diversos direitos fundamentais da mulher que tal tipificação acarreta. ${ }^{1}$

É notório que o tema é dos mais sensíveis ao ordenamento jurídico e à sociedade brasileira, pois, apesar de variadas propostas legislativas, tanto no sentido de legalização quanto no sentido de criminalização e, além de outras decisões no âmbito do próprio judiciário, pouco e lentamente se tem conseguido avançar nesse debate.

Um dos últimos passos dados nesse sentido, inclusive, foi motivado pelo próprio Supremo, que em 2012, ao julgar a Arguição de Descumprimento de Preceito Fundamental (ADPF) 54, autorizou a interrupção da gestação de feto diagnosticado com anencefalia - ainda que não se tenha avançado no cerne da questão, que diz respeito à definição dos contornos do direito à vida em si.

Não obstante a relevância e a urgência da (re)discussão do aborto no Brasil, o presente estudo toma o julgamento do Habeas Corpus 124.306/RJ como contexto para uma análise mais ampla acerca do comportamento da Corte e do modo de exercício da jurisdição constitucional, pois, desde o recebimento do pedido até a sua decisão final, muitos aspectos formais e materiais identificados são sintomáticos de um quadro generalizado de problemas de cunho democrático que perpassam essa atuação. ${ }^{2}$

Diante disso, a presente pesquisa propõe-se a investigar a atuação do Supremo Tribunal Federal no julgamento do Habeas Corpus 124.306/RJ, buscando identificar, a partir de uma detalhada análise jurisprudencial, os parâmetros desta decisão e o que esse julgamento revela sobre o

${ }^{1}$ STF, HC 124.306/RJ, Voto Vista, Min. Roberto Barroso, Proferido em 29/11/2016.

Disponível em:

<http://www.stf.jus.br/arquivo/cms/noticiaNoticiaStf/anexo/HC124306LRB.pdf $>$. Acesso em: 12 de janeiro de 2017.

2 STF, HC 124.306/RJ, Voto Vista, Min. Roberto Barroso, Proferido em 29/11/2016.

Disponível em:

$<$ http://www.stf.jus.br/arquivo/cms/noticiaNoticiaStf/anexo/HC124306LRB.pdf $>$. Acesso em: 12 de janeiro de 2017.

3 JOURNAL OF INSTITUTIONAL STUDIES 2 (2017) 
próprio exercício da jurisdição constitucional pela Corte. ${ }^{3} \mathrm{~A}$ partir desse exame, que dissecará os aspectos formais e materiais da decisão e fará um comparativo com outros precedentes, objetiva-se diagnosticar o modus operandi do exercício da jurisdição constitucional pelo Supremo e quais as implicações democráticas dessa atuação.

Para tanto, empregar-se-á uma metodologia de abordagem indutiva, iniciando com o estabelecimento de premissas pontuais sobre a investigação proposta, como a identificação dos fundamentos da decisão do Habeas Corpus 124.306/RJ e de outros habeas corpus localizados a partir de chaves de busca específicas que serão detalhadas no texto para, então, ampliar esse exame, construindo com base nessas premissas alcançadas a partir de casos concretos uma análise crítica geral de exercício da jurisdição constitucional pelo Tribunal. ${ }^{4}$ Em termos de procedimento, valer-se-á do método monográfico, pois será feito um recorte de tema, tempo e espaço bastante específicos, sem qualquer pretensão de oferecer uma abordagem panorâmica. Por fim, como técnica de pesquisa, adotarse-á a documentação indireta, por meio da pesquisa bibliográfica em livros, periódicos, legislação e jurisprudência.

Considerando o problema, os objetivos e a metodologia definidos, o trabalho será estruturado em três etapas: incialmente, (1) será feito um exame detalhado do Habeas Corpus 124.306/RJ, sobretudo do posicionamento do Ministro Luís Roberto Barroso, cujo voto deflagrou a discussão sobre a inconstitucionalidade do tipo penal do aborto, confrontando o procedimento adotado com outros precedentes da Corte e do Ministro em termos de elementos formais da decisão, pois será apenas num segundo momento (2) que o mérito do julgamento será apreciado; finalmente, definidos os parâmetros concretos de atuação em casos determinados, (3) será feito um estudo crítico sobre o exercício da jurisdição constitucional e sobre o que as decisões analisadas revelam em termos de comportamento dos ministros enquanto membros de uma

${ }_{3}^{3}$ STF, HC 124.306/RJ, Voto Vista, Min. Roberto Barroso, Proferido em 29/11/2016.

Disponível em:

<http://www.stf.jus.br/arquivo/cms/noticiaNoticiaStf/anexo/HC124306LRB.pdf $>$. Acesso em: 12 de janeiro de 2017.

${ }^{4}$ STF, HC 124.306/RJ, Voto Vista, Min. Roberto Barroso, Proferido em 29/11/2016.

Disponível em:

$<$ http://www.stf.jus.br/arquivo/cms/noticiaNoticiaStf/anexo/HC124306LRB.pdf $>$. Acesso em: 12 de janeiro de 2017.

3 JOURNAL OF INSTITUTIONAL STUDIES 2 (2017) 
Corte Constitucional que se pretende democrática. ${ }^{5}$

\section{ANÁlise do HABEAS CORPUS 124.306/RJ A PARTIR DO POSICIONAMENTO DO MINISTRO LUÍS ROBERTO BARROSO}

O estudo ora proposto parte da apreciação do Habeas Corpus 124.306/RJ, julgado pela Primeira Turma do Supremo Tribunal Federal na data de 26 de dezembro de 2016, tendo como relator o Ministro Marco Aurélio e como voto-vista o Ministro Luís Roberto Barroso. ${ }^{6}$

Situa-se o caso concreto na apresentação de um habeas corpus com pedido de medida cautelar, após o desconhecimento de medida idêntica por parte da Sexta Turma do Superior Tribunal de Justiça. Os pacientes constantes no habeas operavam uma clínica de aborto, tendo sido apreendidos em flagrante de delito, no ano de 2013, sendo-lhes imputados os delitos previstos nos artigos 126 e 288 do Código Penal, mais precisamente, a realização de aborto com consentimento da gestante e formação de quadrilha, em concurso material (foram registradas quatro ações cumuladas). ${ }^{7}$

Desse modo, a impetração do habeas junto ao Supremo Tribunal Federal se dá em razão do entendimento de que inexiste, na ação em curso, o preenchimento dos requisitos que abalizam a prisão preventiva dos pacientes, conforme a previsão atual do artigo 312 do Código de Processo Penal. Para sustentar tal linha argumentativa, alega-se que os supostos autores dos delitos são primários, possuem trabalho, residência e bons antecedentes, bem como afirma-se a desproporcionalidade do cerceamento da liberdade, tendo em vista que mesmo em caso de condenação o regime determinado seria aberto (além de não terem

${ }^{5}$ STF, HC 124.306/RJ, Voto Vista, Min. Roberto Barroso, Proferido em 29/11/2016.

Disponível em:

<http://www.stf.jus.br/arquivo/cms/noticiaNoticiaStf/anexo/HC124306LRB.pdf $>$.

Acesso em: 12 de janeiro de 2017.

6 STF, HC 124.306/RJ, Voto Vista, Min. Roberto Barroso, Proferido em 29/11/2016.

Disponível em:

<http://www.stf.jus.br/arquivo/cms/noticiaNoticiaStf/anexo/HC124306LRB.pdf $>$.

Acesso em: 12 de janeiro de 2017.

${ }^{7}$ STF, HC 124.306/RJ, Voto Vista, Min. Roberto Barroso, Proferido em 29/11/2016, p. 3.

Disponível em:

$<$ http://www.stf.jus.br/arquivo/cms/noticiaNoticiaStf/anexo/HC124306LRB.pdf $>$. Acesso em: 12 de janeiro de 2017.

3 JOURNAL OF INSTITUTIONAL STUDIES 2 (2017) 
empreendido fuga no momento do flagrante). ${ }^{8}$

Apesar do posicionamento discordante da Procuradoria Geral da República, o Ministro Marco Aurélio votou pela admissibilidade do habeas corpus e, no tocante ao mérito da causa, pelo afastamento da prisão provisória. ${ }^{9}$

Após a manifestação do Ministro Marco Aurélio, houve o pedido de vista do Ministro Luís Roberto Barroso, que proferiu seu voto iniciando por entender que se tratava de um habeas corpus substitutivo do Recurso Ordinário Constitucional - algo que, sublinha-se, segundo a própria jurisprudência da Corte seria inadmissível, devendo ocasionar a extinção da ação impugnativa sem apreciação de mérito. Todavia, na situação em apreço o Ministro desconsiderou tal jurisprudência justificando que: "em razão da excepcional relevância e delicadeza da matéria, passo a examinar a possibilidade de concessão da ordem de ofício".$^{10}$

Em sentido análogo ao Ministro Marco Aurélio, o Ministro Luís Roberto Barroso pontuou pela inexistência dos requisitos da prisão preventiva, referindo que, na decisão que determinou inicialmente a segregação dos acusados, não havia elementos individualizados que fundamentassem a prisão, tampouco havia bases que levassem a crer na reiteração de atos ilícitos. Na realidade, registrou o Ministro uma crítica incisiva ao referir que foi mencionada de forma genérica a gravidade do fato para abalizar o decreto prisional. ${ }^{11}$

Ademais, reforça as linhas acima a falta de "riscos para a ordem pública ou para a ordem econômica, conveniência para a instrução

8 STF, HC 124.306/RJ, Voto Vista, Min. Roberto Barroso, Proferido em 29/11/2016, p. 3.

Disponível em:

$<$ http://www.stf.jus.br/arquivo/cms/noticiaNoticiaStf/anexo/HC124306LRB.pdf $>$.

Acesso em: 12 de janeiro de 2017.

${ }_{9}$ STF, HC 124.306/RJ, Voto Vista, Min. Roberto Barroso, Proferido em 29/11/2016, p. 3 -

4. Disponível em:

<http://www.stf.jus.br/arquivo/cms/noticiaNoticiaStf/anexo/HC124306LRB.pdf $>$.

Acesso em: 12 de janeiro de 2017.

${ }^{10}$ STF, HC 124.306/RJ, Voto Vista, Min. Roberto Barroso, Proferido em 29/11/2016, p. 4.

Disponível em:

$<$ http://www.stf.jus.br/arquivo/cms/noticiaNoticiaStf/anexo/HC124306LRB.pdf $>$.

Acesso em: 12 de janeiro de 2017.

${ }_{11}$ STF, HC 124.306/RJ, Voto Vista, Min. Roberto Barroso, Proferido em 29/11/2016, p. 4.

Disponível em:

$<$ http://www.stf.jus.br/arquivo/cms/noticiaNoticiaStf/anexo/HC124306LRB.pdf $>$.

Acesso em: 12 de janeiro de 2017.

3 JOURNAL OF INSTITUTIONAL STUDIES 2 (2017) 
criminal ou necessidade de assegurar a aplicação da lei", juntamente aos fatores levantados pela defesa dos pacientes, no sentido de terem residência fixa, trabalho, serem primários e, ao final do processo, no máximo seriam penalizados com pena em regime aberto. ${ }^{12}$

Na segunda parte da decisão, aborda-se a inconstitucionalidade da previsão criminal do aborto, já que a existência de crime também afetaria diretamente a ordem de prisão preventiva. A partir disso, levantam-se os conteúdos básicos para configuração de um delito em um Estado Democrático de Direito, ao exigir-se um bem jurídico relevante, a conduta não ser um exercício regular de direito e ainda contar com uma reação proporcional por parte do ente estatal diante da ofensa produzida. ${ }^{13}$

Assim, gera-se a construção argumentativa de que o bem jurídico envolvido nos delitos de aborto com consentimento da gestante (artigos 124 a 126 do Código Penal), mais precisamente, o feto enquanto vida em potencial, "é evidentemente relevante. Porém, a criminalização do aborto antes de concluído o primeiro trimestre de gestação viola diversos direitos fundamentais da mulher, além de não observar suficientemente o princípio da proporcionalidade" ${ }^{14}$

Prossegue o Ministro fazendo a ressalva de que esse posicionamento não pretende disseminar irrestritamente a prática do aborto. Tão somente busca que ela seja rara e segura, bem como seja evitada sempre que possível com os devidos investimentos nas áreas de educação sexual e saúde pública (métodos contraceptivos).

Esses apontamentos iniciais dão conta do plano formal e apresentam os traços de mérito da decisão, sendo que os últimos merecem análise pormenorizada em um tópico específico. Dito isso, passa-se à apreciação inicial no tocante às nuances formais no processo decisório, conforme os parâmetros estabelecidos pela jurisprudência do Supremo Tribunal Federal.

12 STF, HC 124.306/RJ, Voto Vista, Min. Roberto Barroso, Proferido em 29/11/2016, p. 5.

Disponível em:

<http://www.stf.jus.br/arquivo/cms/noticiaNoticiaStf/anexo/HC124306LRB.pdf $>$.

Acesso em: 12 de janeiro de 2017.

${ }_{13}$ STF, HC 124.306/RJ, Voto Vista, Min. Roberto Barroso, Proferido em 29/11/2016, p. 5.

Disponível em:

<http://www.stf.jus.br/arquivo/cms/noticiaNoticiaStf/anexo/HC124306LRB.pdf $>$.

Acesso em: 12 de janeiro de 2017.

${ }_{14}$ STF, HC 124.306/RJ, Voto Vista, Min. Roberto Barroso, Proferido em 29/11/2016, p. 6.

Disponível em:

$<$ http://www.stf.jus.br/arquivo/cms/noticiaNoticiaStf/anexo/HC124306LRB.pdf $>$.

Acesso em: 12 de janeiro de 2017.

3 JOURNAL OF INSTITUTIONAL STUDIES 2 (2017) 
A partir da decisão do Habeas Corpus 124.306/RJ, realizou-se pesquisa jurisprudencial no Supremo Tribunal Federal, tendo como palavras-chave de busca "habeas corpus" e "recurso ordinário constitucional", em razão de que a apreciação do mérito da causa encontra-se diretamente ligada às possibilidades de cada um dos mecanismos processuais. ${ }^{15}$ Não bastasse o aspecto de reflexão sobre a possível avaliação (ou não) do mérito, há ainda o próprio debate sobre a via adequada para o procedimento, já que, segundo o próprio voto apreciado, a jurisprudência da Corte não admite o habeas em substituição ao recurso ordinário.

Junto às palavras de busca foram determinados outros dois núcleos de especificação, o primeiro foi de margem temporal, iniciando-se em 26 de junho de 2013 e findando em 24 de janeiro de 2017. Esse período foi elegido por se tratar da data inicial em que o Ministro Luís Roberto Barroso foi empossado ao cargo (embora se saiba que a publicação de sua nomeação no Diário Oficial date de 07 de junho de 2013), até o período final após a decisão prolatada, momento em que se realiza o estudo. Outrossim, o segundo fator de delimitação foi a própria presença do Ministro Luís Roberto Barroso no julgamento, ou seja, restringiu-se junto às palavras e período a participação efetiva do mesmo nos casos.

Destarte, demarcaram-se ao menos três linhas de delimitação para a busca jurisprudencial, objetivando maior precisão na reflexão acerca do processo decisório no plano formal, bem como nos detalhes prolatados pelos votos do Ministro em apreço. Com fulcro nisso, obteve-se como resultado um total de trinta acórdãos, o que se passa a analisar.

Dos resultados de busca encontrados, três são descartáveis, tendo em vista que aparecem em razão das palavras-chave, mas não tocam a matéria em apreço, mais precisamente, são: recurso ordinário em habeas corpus 119.392/GO (2013), 120.051/SP (2014), e 118.622/ES (2015) respectivamente os acórdãos de número oito, quinze e vinte e quatro na pesquisa (seguindo a ordem de cronológica gerada pela pesquisa). Tratase de situações semelhantes de recurso ordinário em habeas corpus, sendo que, segundo a posição da Corte, encontram-se alinhado à jurisprudência estabelecida e não possui nenhum vício formal.

Excluídas as situações incompatíveis, restaram vinte e sete acórdãos, sendo o primeiro do Habeas Corpus 111.056/SP, datado de 27 de agosto de 2013, em que, pela primeira vez, se vislumbra o posicionamento do

${ }^{15}$ STF, HC 124.306/RJ, Voto Vista, Min. Roberto Barroso, Proferido em 29/11/2016.

Disponível em:

$<$ http://www.stf.jus.br/arquivo/cms/noticiaNoticiaStf/anexo/HC124306LRB.pdf $>$. Acesso em: 12 de janeiro de 2017.

3 JOURNAL OF INSTITUTIONAL STUDIES 2 (2017) 
Ministro Luís Roberto Barroso na direção de extinguir os habeas substitutivos por inadequação da via processual. ${ }^{16}$ Não há comentários extensos sobre as motivações da postura adotada, apenas remete-se à jurisprudência da Corte, em especial da Primeira Turma, amparada no Habeas Corpus 109.956, de Relatoria do Ministro Marco Aurélio. ${ }^{17}$

Ainda no mesmo ano do acordão inicial, o Habeas Corpus 118.710/SP traz a reiteração jurisprudencial ora estabelecida, porém flexibiliza a resposta ofertada com base no cerceamento da liberdade do paciente em questão. ${ }^{18}$ Deste modo, embora tenha sido mantida a visão da Corte, passa-se a permitir, se houver a expedição de mandado de prisão ou já estiver o paciente sob custódia, a apreciação do habeas substitutivo, como exceção à regra. ${ }^{19}$

Nesse sentido, a brecha acima foi utilizada no ano de 2013 no Habeas Corpus 118.925/RJ. ${ }^{20}$ No caso, apesar de não estar de acordo com a jurisprudência do Supremo Tribunal Federal, o Ministro Luís Roberto Barroso aprecia a questão com base na nova interpretação do Ministro Marco Aurélio, de que, em situações de réus presos, seria possível apreciar a causa (preservando a própria finalidade do habeas enquanto

${ }_{16}$ STF, HC 111.056/SP, Primeira Turma, Min. Red. p/ Acórdão Roberto Barroso, Julgamento em 27/08/2013. Disponível em:

$<$ http://redir.stf.jus.br/paginadorpub/paginador.jsp?docTP=TP\&docID=4689868 >.

Acesso em: 12 de janeiro de 2017.

17 STF, HC 109.956/PR, Primeira Turma, Min. Rel. Marco Aurélio de Mello, Julgamento em 07/08/2012. Disponível em:

$<$ http://redir.stf.jus.br/paginadorpub/paginador.jsp?docTP=TP\&docID=2709684 > .

Acesso em: 12 de janeiro de 2017.

18 STF, HC 118.710/SP, Primeira Turma, Min. Rel. Roberto Barroso, Julgamento em 22/10/2013. Disponível em:

$<$ http://redir.stf.jus.br/paginadorpub/paginador.jsp?docTP=TP\&docID=4872266 >.

Acesso em: 12 de janeiro de 2017.

${ }^{19}$ STF, HC 118.710/SP, Primeira Turma, Min. Rel. Roberto Barroso, Julgamento em 22/10/2013. Disponível em:

$<$ http://redir.stf.jus.br/paginadorpub/paginador.jsp?docTP=TP\&docID=4872266 >.

Acesso em: 12 de janeiro de 2017.

${ }^{20}$ STF, HC 118.925/SP, Primeira Turma, Min. Rel. Roberto Barroso, Julgamento em

17/12/2013. Disponível em:

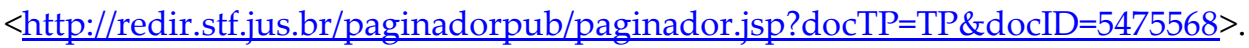

Acesso em: 12 de janeiro de 2017. 
remédio constitucional). ${ }^{21}$

Tudo parece indicar que, pela posição registrada pelo Ministro Luís Roberto Barroso a favor da descriminalização da maconha, seu esforço foi dispendioso e com sensível afinco na reapreciação da matéria, em favor do réu. Apesar de ter reflexos na averiguação de mérito, cabe mencionar que esse é o único julgado em que o aludido ministro realiza uma manifestação claramente de óptica "pessoal", pois, antes de proferir sua manifestação, redige quase uma página para se opor à criminalização da maconha (dispondo contrariamente à política criminal de combate às drogas no Brasil) e ao aprisionamento de jovens, segundo sua interpretação, "pelo tráfico de quantias relativamente pequenas de maconha".22

A peculiaridade do posicionamento acima aludido reflete-se no fato de que a flexibilização da jurisprudência da Primeira Turma do Supremo Tribunal Federal é relativa, pois, na decisão subsequente, no Habeas Corpus 114.747/PE, cujo relator era o Ministro Luís Roberto Barroso, embora o paciente estivesse, segundo relatório, preso (determinação de regime fechado), não houve "flexibilização" para exceção firmada anteriormente. ${ }^{23}$

Diferentemente do que ocorreu no acordão envolvendo o tráfico de maconha, neste, que trata de crack, o Ministro supramencionado não registrou qualquer objeção à atual política criminal de drogas ou mesmo ao encarceramento de jovens por quantias insignificantes. Apenas em grau de comparação, o caso que envolvia maconha tinha cerca de $245 \mathrm{~g}$ enquanto o de crack tinha cerca de 5,6g, o que reverbera indícios de subjetividade na avaliação, mas que, neste momento, não são o alvo na

${ }^{21}$ STF, HC 118.925/SP, Primeira Turma, Min. Rel. Roberto Barroso, Julgamento em 17/12/2013. Disponível em:

$<$ http://redir.stf.jus.br/paginadorpub/paginador.jsp?docTP=TP\&docID=5475568 $>$. Acesso em: 12 de janeiro de 2017.

${ }^{22}$ STF, HC 118.925/SP, Primeira Turma, Min. Rel. Roberto Barroso, Julgamento em 17/12/2013, p. 6. Disponível em:

$<$ http://redir.stf.jus.br/paginadorpub/paginador.jsp?docTP=TP\&docID=5475568 >.

Acesso em: 12 de janeiro de 2017.

${ }^{23}$ STF, HC 114.747/PE, Primeira Turma, Min. Rel. Roberto Barroso, Julgamento em 04/02/2014. Disponível em:

$<$ http://redir.stf.jus.br/paginadorpub/paginador.jsp?docTP=TP\&docID=5626514 $>$. Acesso em: 12 de janeiro de 2017. 
questão. ${ }^{24}$

A prioridade pelas questões procedimentais é constante desde o ingresso do Ministro Luís Roberto Barroso na Suprema Corte. Ao menos em sentido amplo, verifica-se a prioridade da forma sobre o conteúdo na maior parte das vinte e sete decisões analisadas.

Demonstração disso pode ser vista no Habeas Corpus 103.527/RJ, quando, embora no caso concreto dois Ministros (Marco Aurélio e Edson Fachin) tenham acenado forte prejuízo na dosimetria da pena do acusado no que se refere ao mérito, o Ministro Luís Roberto Barroso, amparado pela Ministra Rosa Weber, ancorou-se na jurisprudência do Supremo para justificar que a via processual equivocada tornava inócua a apreciação da dosimetria ou mesmo da matéria em debate. ${ }^{25}$

Igualmente nos casos mais recentes, como no último deles datado de 2016, tratando diretamente com a possibilidade (ou não) de violação de direitos fundamentais (seguindo a lógica estabelecida no recente habeas sobre o aborto, este parece ser o mote para relativizar o posicionamento jurisprudencial), em especial aqueles ligados a comunicações e dados pessoais, o entendimento que prevaleceu foi no sentido de que a via processual adotada era incompatível. Similarmente, reitera o Ministro Luís Roberto Barroso que, mesmo no que toca o mérito da discussão (a respeito da ilicitude da prova), ainda assim não seria adequada a tese da defesa, já que a Segunda Turma do Supremo com o Ministro Gilmar Mendes já havia firmado posição distinguindo comunicações telefônicas e registros, o que acabava por esvaziar o debate. ${ }^{26}$

Diante do quadro exposto, há um denominador comum nas manifestações em sede de habeas substitutivo do recurso ordinário, que é a referência ao julgado do Habeas Corpus 109.956/PR, datado de 2012 e de relatoria do Ministro Marco Aurélio, indicando que seria importante

${ }^{24}$ STF, HC 114.747/PE, Primeira Turma, Min. Rel. Roberto Barroso, Julgamento em 04/02/2014. Disponível em:

$<$ http://redir.stf.jus.br/paginadorpub/paginador.jsp?docTP=TP\&docID=5626514 $>$.

Acesso em: 12 de janeiro de 2017.

${ }_{25}$ STF, HC 103.527/RJ, Primeira Turma, Min. Red. p/ Acórdão Roberto Barroso,

Julgamento em 08/09/2015. Disponível em:

$<$ http://redir.stf.jus.br/paginadorpub/paginador.jsp?docTP=TP\&docID=9676757> .

Acesso em: 12 de janeiro de 2017.

${ }^{26}$ STF, AgR-HC 124.322/RS, Primeira Turma, Min. Rel. Roberto Barroso, Julgamento em 09/120/2016. Disponível em:

$<$ www.stf.jus.br/portal/inteiroTeor/obterInteiroTeor.asp?idDocumento=12236234 $>$. Acesso em: 12 de janeiro de 2017.

3 JOURNAL OF INSTITUTIONAL STUDIES 2 (2017) 
apresentar breves apontamentos sobre tal decisão. ${ }^{27}$

A construção do Ministro Marco Aurélio que serve de base jurisprudencial na Primeira Turma do Supremo Tribunal Federal inicia sua fundamentação com um argumento empírico, no sentido de que o habeas substitutivo vinha causando um problema de demanda, já que, tanto no Supremo Tribunal Federal, quanto no Superior Tribunal de Justiça, o volume de habeas nessas condições era imensamente superior aos do recurso ordinário. Cita-se para corroborar tal afirmativa o dado de que, no primeiro semestre do ano de 2012, o tribunal havia recebido 2.181 habeas e somente 108 recursos ordinários, o que convalida que naquele momento o habeas substitutivo estava a ser utilizado como regra e não como exceção. ${ }^{28}$

Ademais, menciona-se a queda em desuso que estava sendo reservada ao recurso ordinário, embora este estivesse devidamente previsto nas vias constitucionais e fosse a ferramenta adequada em grande parte dos casos. Em sequência, aponta a decisão para o fato de que não há previsão legal para utilização do habeas substitutivo, enquanto, em contrapartida, há previsão expressa para adoção do recurso ordinário no texto constitucional. ${ }^{29}$

Assim, consigna o Ministro Marco Aurélio que os ajustes em relação ao recurso ordinário visam "restabelecer a eficácia dessa ação maior, a valia da Carta Federal no que prevê não o habeas substitutivo, mas o recurso ordinário - a correção de rumos" ${ }^{30}$ Registre-se que, apesar do reconhecimento do erro procedimental, resta claro que isso não atinge a

${ }^{27}$ STF, HC 109.956/PR, Primeira Turma, Min. Rel. Marco Aurélio de Mello, Julgamento em 07/08/2012. Disponível em:

$<$ http://redir.stf.jus.br/paginadorpub/paginador.jsp?docTP=TP\&docID=2709684 > .

Acesso em: 12 de janeiro de 2017.

${ }_{28}$ STF, ADPF 54, Tribunal Pleno, Min. Rel. Marco Aurélio de Mello, Julgamento em 12/04/2012. Disponível em:

$<$ www.stf.jus.br/portal/processo/verProcessoPeca.asp?id=136389880\&tipoApp=.pdf $>$.

Acesso em: 17 de janeiro de 2017.

${ }_{29}$ STF, ADPF 54, Tribunal Pleno, Min. Rel. Marco Aurélio de Mello, Julgamento em 12/04/2012. Disponível em:

$<$ www.stf.jus.br/portal/processo/verProcessoPeca.asp?id=136389880\&tipoApp=.pdf $>$.

Acesso em: 17 de janeiro de 2017.

${ }_{30}$ STF, ADPF 54, Tribunal Pleno, Min. Rel. Marco Aurélio de Mello, Julgamento em 12/04/2012, p. 8. Disponível em:

$<$ www.stf.jus.br/portal/processo/verProcessoPeca.asp?id=136389880\&tipoApp=.pdf $>$. Acesso em: 17 de janeiro de 2017. 
concessão de ordem de ofício.

Com base na referência jurisprudencial adotada pela Primeira Turma, juntamente às demais decisões apreciadas até o presente momento, podese imputar que no Habeas Corpus 124.306/RJ, acerca do tema do aborto, do ponto de vista formal se resguarda dos próprios posicionamentos firmados no Supremo Tribunal Federal. ${ }^{31}$

Essa percepção se dá a partir de que: a) um habeas substitutivo não é admissível, tendo em vista a previsão do recurso ordinário, o que ocasionou diversas rejeições pelo Ministro Luís Roberto Barroso entre os anos de 2013-2016; b) porém, a mesma base decisória firmou que, diante de paciente preso (ou com mandado de prisão), seria possível analisar o habeas, o que ocorreu no caso em apreço $\mathrm{o}^{32}$; c) não bastando tal verificação, há ainda a apreciação da ordem de ofício, a qual novamente encontra-se abalizada na Primeira Turma, pois utiliza a decisão de 2012 como referência e, nessa, verifica-se a atenção em preservar tal aspecto, mesmo que de praxe seja rejeitado o habeas.

Todavia, existem nuances de forma que não foram observadas pelo referido Ministro, pois trazer como fundamento para análise a relevância da matéria ou mesmo a afetação de direitos fundamentais trata-se de argumentação inexistente em outros julgados, conforme já verificado desde o ingresso do mesmo na Corte, além de incompatível com a jurisprudência firmada. Igualmente, não resta claro se o referido habeas foi convertido em recurso ordinário constitucional, pois somente isso traria, do ponto de vista processual, a legitimidade para apreciação acerca da dita inconstitucionalidade do tipo penal nas circunstâncias fáticas estabelecidas, já que o habeas é remédio que não se presta à dilação probatória ${ }^{33}$, necessária para reflexão acerca do mérito em pauta.

${ }^{31}$ STF, HC 124.306/RJ, Voto Vista, Min. Roberto Barroso, Proferido em 29/11/2016.

Disponível em:

$<$ http://www.stf.jus.br/arquivo/cms/noticiaNoticiaStf/anexo/HC124306LRB.pdf $>$. Acesso em: 12 de janeiro de 2017.

32 STF, HC 124.306/RJ, Voto Vista, Min. Roberto Barroso, Proferido em 29/11/2016.

Disponível em:

$<$ http://www.stf.jus.br/arquivo/cms/noticiaNoticiaStf/anexo/HC124306LRB.pdf $>$. Acesso em: 12 de janeiro de 2017.

${ }^{33}$ LOPES JÚNIOR, Aury. Direito Processual Penal. 11 $1^{\underline{a}}$ ed. São Paulo, SP: Saraiva, 2014, p. 983. 


\section{A APRECIAÇÃO DO MÉRITO DO HABEAS CORPUS 124.306/RJ}

A apreciação do conteúdo tratado no voto do Ministro Luís Roberto Barroso no Habeas Corpus 124.306/RJ inicia-se por apontar que a ordem de ofício em um habeas seria restrita à verificação primária do voto, pois é nessa parte que se debruça sobre a falta de condições para prisão preventiva. ${ }^{34}$ Significa dizer que, no caso concreto, não havia espaço para debates mais profundos sobre a matéria, tendo em vista que o remédio constitucional não serve a tal finalidade, motivo pelo qual a decisão apresenta uma segunda parte um tanto questionável.

Desse modo, por mais que se objetive a proteção dos direitos e garantias dos acusados em um processo criminal, o qual deve possuir uma duração razoável (devidamente alinhada com a celeridade processual) conforme dispõe o texto constitucional ${ }^{35}$, isso não indica a permissão para que o magistrado possa alterar a própria finalidade (constitucional) do instrumento processual. Em síntese, por mais que exista o desejo de debater o conteúdo da causa, não se pode simplesmente adentrar esse campo fora dos parâmetros estabelecidos em lei.

Apenas em adendo, no presente habeas registra-se claramente que o mesmo deve ser extinto sem julgamento de mérito pelo equívoco procedimental, ou seja, em nenhum momento ele foi recebido como se fosse um instrumento diferente, no caso um recurso ordinário. Se, por ventura, ocorresse a conversão do habeas em recurso, ao menos deveriam ser levantados os fundamentos processuais penais, que se encontram no artigo 579 do Código de Processo Penal, bem como a alusão à aplicabilidade do princípio da fungibilidade, o qual seria inserido em uma zona cinzenta acerca da manifestação jurisdicional. ${ }^{36}$

Entretanto, tal alteração processual não ocorreu e o Ministro Luís Roberto Barroso passou a analisar a constitucionalidade da matéria, visto que a consideração do fato como criminoso é um pressuposto para prisão. Embora, como já referenciado, tal construção esteja distante da ordem de

${ }^{34}$ STF, HC 124.306/RJ, Voto Vista, Min. Roberto Barroso, Proferido em 29/11/2016.

Disponível em:

<http://www.stf.jus.br/arquivo/cms/noticiaNoticiaStf/anexo/HC124306LRB.pdf $>$.

Acesso em: 12 de janeiro de 2017.

${ }^{35}$ Cf. GLOECKNER, Ricardo Jacobsen. Risco e Processo Penal: uma análise a partir dos Direitos Fundamentais do Acusado. Salvador, BA: JusPodivm, 2009, p. 346-349. 36 WAMBIER, Teresa Arruda Alvim. O óbvio que não se vê: a nova forma do Princípio da Fungibilidade. Argumenta Journal Law, No. 6, 2006, p. 38. 
ofício, alude-se que a compatibilidade constitucional se dá com a proteção de um bem jurídico relevante, "que o comportamento incriminado não constitua exercício legítimo de um direito fundamental e que haja proporcionalidade entre a ação praticada e a reação estatal" ${ }^{37}$

Com base nos três elementos citados, apresenta-se o questionamento acerca das incriminações dos artigos 124 e 126 do Código Penal, ambos na modalidade consensual, de maneira que a gestante toma a decisão de interromper a gestação de forma livre e consciente. Em relação à vida intrauterina ter relevância como bem jurídico, não há dúvidas, segundo o Ministro, "porém, a criminalização do aborto antes de concluído o primeiro trimestre de gestação viola diversos direitos fundamentais da mulher, além de não observar suficientemente o princípio da proporcionalidade" ${ }^{38}$

Portanto, vislumbra-se que o cerne decisório centra-se nos direitos fundamentais, apesar de que, desde a entrada no Supremo Tribunal Federal, esse argumento nunca foi antes levantado pelo Ministro Luís Roberto Barroso para sustentar nenhuma demanda semelhante em casos de habeas corpus substitutivos de recurso ordinário.

Dito isso, a decisão em apreço introduz os direitos fundamentais, em clara alusão à dinâmica básica da doutrina, no sentido de considerar que os direitos fundamentais são direitos humanos garantidos na órbita interna constitucional. Indica-se, assim, a visão ainda ligada ao pensamento de direitos pós-violatórios, ignorando a necessidade de repensar esses mesmos direitos por meio de uma visão crítica dos direitos humanos. ${ }^{39}$ Prossegue no raciocínio ao aduzir a dignidade humana como elemento central, com base no pensamento kantiano, a fim de asseverar o valor de cada indivíduo e sua imperiosa autonomia. Igualmente, afirma a aplicação imediata dos direitos fundamentais, bem como a sua sujeição a limites e restrições, sendo que podem ocasionar conflitos entre princípios ou direitos, o que apontaria, nos casos concretos, como solução

${ }_{37}$ STF, HC 124.306/RJ, Voto Vista, Min. Roberto Barroso, Proferido em 29/11/2016, p. 5. Disponível em:

$<$ http://www.stf.jus.br/arquivo/cms/noticiaNoticiaStf/anexo/HC124306LRB.pdf $>$.

Acesso em: 12 de janeiro de 2017.

${ }^{38}$ STF, HC 124.306/RJ, Voto Vista, Min. Roberto Barroso, Proferido em 29/11/2016, p. 6.

Disponível em:

$<$ http://www.stf.jus.br/arquivo/cms/noticiaNoticiaStf/anexo/HC124306LRB.pdf $>$. Acesso em: 12 de janeiro de 2017.

${ }^{39}$ Cf. SÁNCHEZ RUBIO, David; SENENT DE FRUTOS, Juan Antonio. Teoría Crítica del Derecho: Nuevos Horizontes. Sevilla: Centro de Estudios Jurídicos y Sociales Mispat, 2013.

3 JOURNAL OF INSTITUTIONAL STUDIES 2 (2017) 
a proporcionalidade, claramente estruturada no pensamento de Robert Alexy (e sua organização em subprincípios da proporcionalidade adequação, necessidade e proporcionalidade em sentido estrito), conforme evidenciam as próprias referências do Ministro Luís Roberto Barroso. ${ }^{40}$

Registra-se aqui um primeiro estranhamento no conteúdo explanado, pois, na elaboração da decisão, o Ministro fala em "razoabilidade ou proporcionalidade", o que gera dúvida, já que há uma série de autores que apresenta os dois princípios como consideravelmente distintos, tanto em sua origem, quanto em sua aplicação. Ademais, a própria teoria de Robert Alexy trabalha essencialmente com a proporcionalidade e não com a razoabilidade como sendo uma espécie de sinônimo ou equivalente. ${ }^{41}$

A linha de pensamento continua ao retomar a perspectiva dos direitos da mulher, citando o tratamento globalizado da questão, na direção de o Estado não servir como instrumento de inviabilização do aborto e, ao mesmo tempo, que tal prática não é algo "prazeroso", mas o Estado não precisa piorar a situação através de um processo penal. Esses argumentos são direcionados à legitimidade do comportamento da gestante, o que desse modo resultaria em uma incoerência na incriminação da ação do profissional da saúde envolvido na conduta.

Soma-se ainda a menção à ausência de uma concepção definida sobre o início da vida em gestação, referindo duas teorias principais: a da concepção e da formação do sistema nervoso (terceiro mês de gestação). Remanesce, neste ponto, forte simplificação do debate, visto que quando julgada a ADPF 54 foram mencionadas diversas vertentes teóricas sobre o tema. ${ }^{42}$ Porém, neste momento, direcionou-se a incerteza jurídica sobre a vida, juntamente ao fato da dependência do embrião do corpo materno, o que tornaria impossível sua manutenção fora deste contexto e sendo tal premissa fática a base para a discussão dos direitos fundamentais da

${ }^{40}$ STF, HC 124.306/RJ, Voto Vista, Min. Roberto Barroso, Proferido em 29/11/2016, p. 7. Disponível em:

$<$ http://www.stf.jus.br/arquivo/cms/noticiaNoticiaStf/anexo/HC124306LRB.pdf $>$. Acesso em: 12 de janeiro de 2017.

${ }^{41}$ Cf. ALEXY, Robert. Teoria dos Direitos Fundamentais. Trad. Virgílio Afonso da Silva. São Paulo, SP: Malheiros, 2008.

${ }^{42}$ Cf. STF, ADPF 54, Tribunal Pleno, Min. Rel. Marco Aurélio de Mello, Julgamento em 12/04/2012. Disponível em:

$<$ www.stf.jus.br/portal/processo/verProcessoPeca.asp?id=136389880\&tipoApp=.pdf $>$. Acesso em: 17 de janeiro de 2017.

3 JOURNAL OF INSTITUTIONAL STUDIES 2 (2017) 
mulher. ${ }^{43}$

$\mathrm{O}$ primeiro direito fundamental atingido, de acordo com o voto em apreço, é a autonomia, pois essa, ao ser atingida, estaria a lesionar a liberdade individual e, em essência, a dignidade humana que funciona como seu núcleo. Concentra-se aqui nas opções de vida e escolhas de um ser humano livre e consciente, de modo que: "quando se trate de uma mulher, um aspecto central de sua autonomia é o poder de controlar o próprio corpo e de tomar as decisões a ele relacionadas, inclusive a de cessar ou não uma gravidez". ${ }^{44}$

Destarte, o Ministro Luís Roberto Barroso critica exatamente a postura interventiva do Estado, por meio de seus agentes do poder coercitivo (polícia, Ministério Público, Judiciário), ao obrigar a mulher à continuidade de uma gestação inicial (primeiros meses), como se seu útero estivesse a serviço da sociedade, ignorando completamente sua autonomia e autodeterminação. Embora não tenha tocado nesta faceta do assunto, seria cabível aludir a noção de autonomia reprodutiva, tendo em vista que, por mais que esse debate seja de ordem nacional, tal referencial jurídico sobre os direitos da mulher já figura em documentos internacionais sobre o tema. ${ }^{45}$

Logo após, apresenta-se o segundo direito atingido: a integridade física e psíquica da mulher. Tal direito encontra previsão normativa no artigo $5^{\circ}$, caput e inciso III da Constituição, apresentando as seguintes ofensas ao exigir a continuidade de uma gravidez indesejada:

A integridade física é abalada porque é o corpo da mulher que sofrerá as transformações, riscos e consequências da gestação. Aquilo que pode ser uma bênção quando se cuide de uma gravidez desejada, transmuda-se em tormento quando indesejada. A integridade psíquica, por sua vez, é afetada

${ }^{43}$ STF, HC 124.306/RJ, Voto Vista, Min. Roberto Barroso, Proferido em 29/11/2016, p. 9. Disponível em:

<http://www.stf.jus.br/arquivo/cms/noticiaNoticiaStf/anexo/HC124306LRB.pdf $>$.

Acesso em: 12 de janeiro de 2017.

${ }^{44}$ STF, HC 124.306/RJ, Voto Vista, Min. Roberto Barroso, Proferido em 29/11/2016, p. 9.

Disponível em:

$<$ http://www.stf.jus.br/arquivo/cms/noticiaNoticiaStf/anexo/HC124306LRB.pdf $>$.

Acesso em: 12 de janeiro de 2017.

${ }^{45}$ SARMENTO, Daniel. Legalização do Aborto e Constituição. Alcilene Cavalvante e

Dulce Xavier (Orgs.). Em Defesa da Vida: Aborto e Direitos Humanos. São Paulo, SP:

Católicas pelo Direito de Decidir, 2006, p. 159.

3 JOURNAL OF INSTITUTIONAL STUDIES 2 (2017) 
pela assunção de uma obrigação para toda a vida, exigindo renúncia, dedicação e comprometimento profundo com outro ser. Também aqui, o que seria uma bênção se decorresse de vontade própria, pode se transformar em provação quando decorra de uma imposição heterônoma. Ter um filho por determinação do direito penal constitui grave violação à integridade física e psíquica de uma mulher. ${ }^{46}$

Nesse sentido, os fundamentos dispostos buscam dimensionar o espectro jurídico de afetação da mulher nas mais diferentes vertentes, ou seja, tanto sua liberdade é atingida ao ter uma imposição jurídico-penal, lesando sua autonomia psíquica, quanto há violações ao seu corpo que é sentenciado a modificações contra sua vontade e, ao que parece, para atender aos desejos estatais.

Em continuidade, chega-se ao terceiro direito abordado, mais precisamente os direitos sexuais e reprodutivos da mulher, os quais abrangem seu processo decisório acerca de se deseja ter filhos ou não e quando almeja tal fato, tudo isso livre de qualquer ato de violência, discriminação ou coerção, juntamente à preservação da melhor saúde sexual e reprodutiva possível. Salutar mencionar que o Ministro Luís Roberto Barroso faz questão de enfatizar as discriminações sofridas e opressões históricas contra as mulheres, dando ênfase à necessidade de garantir uma vida sexual ativa e prazerosa distante de preconceitos, mesmo quando se sabe do ônus que a gravidez acarreta para mulher. ${ }^{47}$

Assim, o reconhecimento dos prejuízos históricos causados às mulheres, em especial a sua saúde sexual e reprodutiva, demonstra alinhamento com as pautas feministas sobre o tema, já que tais direitos vêm sendo pleiteados desde a segunda onda do movimento feminista, a qual, além da violência doméstica, trazia ao debate questões como a repressão sexual decorrente do modelo social patriarcal. ${ }^{48}$

${ }^{46}$ STF, HC 124.306/RJ, Voto Vista, Min. Roberto Barroso, Proferido em 29/11/2016, p. 9 10. Disponível em:

$<$ http://www.stf.jus.br/arquivo/cms/noticiaNoticiaStf/anexo/HC124306LRB.pdf $>$. Acesso em: 12 de janeiro de 2017.

${ }^{47}$ STF, HC 124.306/RJ, Voto Vista, Min. Roberto Barroso, Proferido em 29/11/2016, p.

10. Disponível em:

$<$ http://www.stf.jus.br/arquivo/cms/noticiaNoticiaStf/anexo/HC124306LRB.pdf $>$. Acesso em: 12 de janeiro de 2017.

${ }^{48}$ ALIMENA, Carla Marrone. A tentativa do (im)possível: feminismos e criminologias. Rio de Janeiro, RJ: Lumen Juris, 2011, p. 20-21. 
Ao lado dessas considerações históricas, alberga-se a fundamentação com fulcro nos direitos humanos da mulher. Para tanto referenciam-se a Conferência do Cairo (Conferência Internacional de População e Desenvolvimento) de 1994 e a IV Conferência Mundial sobre a Mulher de 1995 em Pequim.

Esses dois marcos internacionais são referenciados como bases para os direitos sexuais e reprodutivos, podendo-se adicionar ainda a Conferência de Copenhagem de 1994, todos eles resultando em um mesmo denominador comum: "a criminalização do aborto resulta, assim, como uma violação a direitos humanos internacionalmente protegidos, em particular nas esferas da sexualidade e reprodução". ${ }^{49}$

Portanto, seguindo entendimento similar o Ministro Luís Roberto Barroso compreende que a atual incriminação por parte do Código Penal atinge diretamente a autodeterminação reprodutiva da mulher, tendo em vista que impede sua disposição sobre a continuidade ou não da gestação com base na coerção estatal. Igualmente, o dispositivo penal ainda causa danos à saúde reprodutiva, mencionado, nesse ponto, os altos índices de mortalidade causados pela atual política coercitiva.

Soma-se a tais ofensas de direitos a menção, mesmo que breve, da desigualdade de gênero que, além das marcas históricas, acarretam danos a nível social e econômico para as mulheres, sendo que isso provocou (e ainda provoca) desigualdades, visões estereotipadas da identidade e do próprio papel social das mulheres. "Há, por exemplo, uma visão idealizada em torno da experiência da maternidade, que, na prática, pode constituir um fardo para algumas mulheres"..$^{50}$

Em resumo, as considerações da desigualdade levam à conclusão de que se não for garantido o direito de decidir sobre a manutenção ou não da gestação, permaneceria clara discrepância entre homens e mulheres, pois apenas às mulheres recaem os ônus da gestação.

Por fim, a última base para ofensa aos direitos fundamentais da mulher apresenta-se na forma de discriminação social. Considera o Ministro que a incriminação atinge mais fortemente as mulheres pobres, pois essas não podem recorrer a clínicas particulares e tampouco ao

${ }^{49}$ PIOVESAN, Flávia. Direitos Sexuais e Reprodutivos: Aborto Inseguro como Violação aos Direitos Humanos. In: Daniel Sarmento e Flávia Piovesan (Org.). Nos Limites da Vida: Aborto, Clonagem Humana e Eutanásia sob a perspectiva dos Direitos Humanos. Rio de Janeiro, RJ: Lumen Juris, 2007, p. 66.

${ }^{50}$ STF, HC 124.306/RJ, Voto Vista, Min. Roberto Barroso, Proferido em 29/11/2016, p. 11. Disponível em:

$<$ http://www.stf.jus.br/arquivo/cms/noticiaNoticiaStf/anexo/HC124306LRB.pdf $>$. Acesso em: 12 de janeiro de 2017.

3 JOURNAL OF INSTITUTIONAL STUDIES 2 (2017) 
sistema público de saúde, tendo assim que se submeter a procedimentos em locais clandestinos e sem qualquer segurança a sua integridade física, sexual ou mesmo psíquica.

Ante esse quadro, conclui que a imputação do aborto como crime antes do primeiro trimestre causa lesão ao núcleo essencial de diversos direitos humanos e fundamentais da mulher, o que não se considera constitucionalmente aceitável. ${ }^{51}$

\section{O HABEAS CoRPuS 124.306/RJ E O QUE O SEU JULGAMENTO REPRESENTA EM TEMOS DE ATUAÇÃO DA JURISDIÇÃO CONSTITUCIONAL}

Recapitulando, a presente investigação propõe-se à análise de um caso concreto específico: um habeas corpus com pedido de medida cautelar de afastamento da prisão provisória, cujos pacientes operavam uma clínica de aborto e que, apesar de ter sido considerado um substitutivo do recurso ordinário constitucional - o que, segundo entendimento até então predominante na jurisprudência do Supremo Tribunal Federal (em especial da primeira turma), ocasionaria a sua extinção sem apreciação de mérito -, não só foi recebido e provido, como deflagrou uma nova frente de discussão acerca da inconstitucionalidade do crime de aborto.

Diz-se de uma "nova frente" de discussão porque, no ano de 2012, a Corte teve uma oportunidade inédita de enfrentar esse tema por ocasião do julgamento da ADPF 54, em que se autorizou a antecipação terapêutica do parto para interromper a gestação de feto diagnosticado com anencefalia. Embora os votos dos ministros tenham apenas tangenciado a questão mais delicada que permeava o caso - os contornos do direito à vida, em si -, a ação postulava a interpretação conforme à Constituição dos artigos 124, 126, caput e 128, I e II, do Código Penal, o que, sem dúvida, permitiria a análise sobre eventual inconstitucionalidade material do tipo penal atacado.

Para o ano de 2017, ainda, encontra-se na pauta de julgamento do Supremo Tribunal Federal a Ação Direta de Inconstitucionalidade (ADI) 5.581 (cumulada com ADPF), que, em demanda ajuizada em agosto de

${ }^{51}$ STF, HC 124.306/RJ, Voto Vista, Min. Roberto Barroso, Proferido em 29/11/2016, p. 11-12. Disponível em:

$<$ http://www.stf.jus.br/arquivo/cms/noticiaNoticiaStf/anexo/HC124306LRB.pdf $>$. Acesso em: 12 de janeiro de 2017.

3 JOURNAL OF INSTITUTIONAL STUDIES 2 (2017) 
2016 pela Associação Nacional dos Defensores Públicos (ANADEP), pretende assegurar, dentre outros direitos, a possibilidade de mulheres comprovadamente infectadas pelo Zika Vírus interromperem a gestação.

Assim, enquanto todas as expectativas de ver a discussão sobre o aborto no Brasil ser retomada pela Corte recaiam sobre a ADI 5.581, o julgamento do Habeas Corpus 124.306/RJ antecipou a polêmica e reascendeu o debate com um dado novo: a possibilidade de interrupção da gestação até o terceiro mês sem que se configure crime (sob as justificativas destacadas anteriormente que foram desenvolvidas no votovista do Ministro Luís Roberto Barroso).52

De imediato, dois aspectos são dignos nota: a) um habeas corpus substitutivo de recurso ordinário constitucional que, segundo jurisprudência do próprio Supremo Tribunal Federal, não poderia ter sido admitido, ser o veículo de uma discussão tão necessária, porém tão delicada para a sociedade brasileira; b) as expectativas desse assunto premente (e de algum avanço na questão) estarem lançadas, mais uma vez, sobre a Corte Constitucional, ao invés do Legislativo.

Sobre o primeiro tópico, em especial, repisa-se, de imediato, a análise anterior dos aspectos formais e materiais do julgamento do Habeas Corpus 124.306/RJ, bem como das demais decisões que foram usadas como referências de investigação dos parâmetros de decisão do Supremo Tribunal Federal em situações semelhantes. ${ }^{53}$ Nesse momento, o que se pretende adicionar à investigação, para além do já constatado - a inconsistência na argumentação que autoriza o recebimento de uma demanda historicamente recusada pela Corte e a dificuldade de compreensão quanto ao fator de distinção que justificaria tratamento tão diverso e dissonante dos demais precedentes -, diz respeito ao espaço "criado" pelos próprios Ministros para protagonizarem um debate que sequer era objeto (pelo menos não de modo direto) do pedido.

Não se pretende entrar na discussão, pelo menos não agora, acerca da legitimidade da apreciação dessa matéria pelo Supremo Tribunal Federal, pois enquanto guardião da Constituição, é evidente que toda e qualquer possibilidade de lesão a direito fundamental autoriza a sua atuação -

${ }^{52}$ STF, HC 124.306/RJ, Voto Vista, Min. Roberto Barroso, Proferido em 29/11/2016.

Disponível em:

<http://www.stf.jus.br/arquivo/cms/noticiaNoticiaStf/anexo/HC124306LRB.pdf $>$.

Acesso em: 12 de janeiro de 2017.

${ }^{53}$ STF, HC 124.306/RJ, Voto Vista, Min. Roberto Barroso, Proferido em 29/11/2016.

Disponível em:

<http://www.stf.jus.br/arquivo/cms/noticiaNoticiaStf/anexo/HC124306LRB.pdf $>$. Acesso em: 12 de janeiro de 2017.

3 JOURNAL OF INSTITUTIONAL STUDIES 2 (2017) 
embora não se possa perder de vista que a legitimidade quanto à forma dessa intervenção seja tão essencial quanto o seu conteúdo material.

Contudo, o tema "aborto" talvez seja dos mais sensíveis à sociedade brasileira, o que sinaliza para a necessidade, no mínimo, de um diálogo abrangente e democrático sobre o assunto (embora qualquer medida que se adote nesse sentido já chegará em atraso, um atraso que vem tirando vidas de mulheres há anos, existindo inúmeros estudos e documentos, nacionais e internacionais, comprovando essa assertiva). ${ }^{54}$ Então, por que (n)o Supremo? Por que agora e não em 2012?

Uma busca simples nos projetos de lei em tramitação na Câmara dos Deputados que contemplem, direta ou indiretamente, o termo "aborto", revela 84 registros. As propostas são diversas, mas é possível perceber claramente uma tendência contrária à legalização: proibição de método de anticoncepção de emergência (pílula do dia seguinte) (PL 1413/2007); tipificação como crime contra a vida o anúncio de meio abortivo (PL 5069/2013); previsão de aumento de pena no caso de aborto cometido em razão da microcefalia ou anomalia do feto (PL 4396/2016); inclusão do aborto provocado pela gestante, ou por terceiros, com o seu

${ }^{54}$ Um relatório do ano de 2011, publicado pela Organização Mundial da Saúde (Women and health: today's evidence tomorrow's agenda) documenta essa realidade conhecida no Brasil, de que a restrição legal ao aborto não impede a sua prática. Quase 70.000 mulheres morrem anualmente devido a complicações do aborto inseguro, uma tendência comprovada quando esses procedimentos são realizados em um contexto de ilegalidade, pois acabam sendo oferecidos por pessoas não qualificadas e em precárias condições de higiene. Outro dado que também não surpreende é o de que as mulheres pobres são as que correm mais riscos. Em contrapartida, onde há poucas restrições ao aborto seguro, os óbitos e as complicações são reduzidos drasticamente. Cf. ORGANIZAÇÃO MUNDIAL DA SAÚDE. Mulheres e Saúde: evidências de hoje, agenda de amanhã. Trad. Jean-Pierre Barakat. Genebra: WHO Press, 2011, p. 42-43. Disponível em: $<$ http://www.who.int/eportuguese/publications/Mulheres Saude.pdf?ua=1 $>$. Acesso em: 14 de maio de 2017. A própria ONU já recomendou ao Estado brasileiro que reveja sua postura quanto ao tratamento da questão: "Ensure access to reproductive health care, including high quality prenatal care, and information on sexual and reproductive health, contraception and emergency contraception, and safe abortion to all women without discrimination". ORGANIZAÇÃO DAS NAÇÕES UNIDAS. Draft report of the Working Group on the Universal Periodic Review: Brazil. Geneva: ONU, 2017. Disponível em: $<\underline{\text { http://acnudh.org/wp- }}$ content/uploads/2017/05/A HRC WG.6 27 L.9 Brazil.pdf>. Acesso em: 29 de janeiro 2018. 
consentimento, como crime hediondo (PL 4703/1998; PL 3207/2008; PL 7443/2006); previsão de pensão e assistência à mãe e à criança nascida de gravidez decorrente de estupro (PL 3748/2008; PL 1763/2007); instituição do Dia Nacional de Conscientização Antiaborto (PL 5617/2016). ${ }^{55}$

De igual modo, a pesquisa por projetos de lei em tramitação no Senado Federal com a mesma chave de busca aponta quatorze resultados, destacando-se que quatro destes projetos (PLS 312/2004, PLS 227/2004, PLS 183/2004 e PLS 50/2011), anteriores à decisão da ADPF 54, que autorizou a interrupção da gestação diante de diagnóstico de feto com anencefalia, já pretendiam a inclusão deste fato como causa excludente de antijuridicidade quanto ao crime de aborto (um possível inciso III no artigo 128 do Código Penal). ${ }^{56}$

Também chama atenção que, posteriormente ao julgamento da ADPF 54 pelo Supremo Tribunal Federal (abril de 2012), foram apresentadas no Senado duas propostas legislativas contrárias à decisão, uma tratando especificamente "sobre o crime de interrupção de gravidez em razão de diagnóstico de anencefalia" (PLS 287, de agosto de 2012), a outra visando criminalizar o aborto em qualquer estágio da gestação (PLS 461/2016). ${ }^{57}$

Além disso, é importante registrar que tramita, no Senado, um projeto de reforma do Código Penal, no qual também são debatidas alterações quanto ao crime de aborto, inclusive, em prol do que equivaleria à legalização da prática no país ${ }^{58}$ (mas contando com algumas ressalvas,

${ }^{55}$ Disponível em: $<$ http://www.camara.leg.br/>. Acesso em: 14 de maio de 2017.

${ }^{56}$ STF, ADPF 54, Tribunal Pleno, Min. Rel. Marco Aurélio de Mello, Julgamento em 12/04/2012. Disponível em:

$<$ www.stf.jus.br/portal/processo/verProcessoPeca.asp? $\mathrm{id}=136389880 \&$ tipoApp=.pdf $>$. Acesso em: 17 de janeiro de 2017; e Disponível em: <http://www25.senado.leg.br $>$. Acesso em: 14 de maio de 2017.

57 STF, ADPF 54, Tribunal Pleno, Min. Rel. Marco Aurélio de Mello, Julgamento em 12/04/2012. Disponível em:

$<$ www.stf.jus.br/portal/processo/verProcessoPeca.asp?id=136389880\&tipoApp=.pdf $>$. Acesso em: 17 de janeiro de 2017; e Disponível em: <http://www25.senado.leg.br $>$. Acesso em: 14 de maio de 2017.

${ }^{58}$ Eis a redação proposta pelo Projeto de Lei do Senado 236/2012 para o artigo 128 do Código Penal: "Art. 128. - Não há crime de aborto: I - se houver risco à vida ou à saúde da gestante; II - se a gravidez resulta de violação da dignidade sexual, ou do emprego não consentido de técnica de reprodução assistida; III - se comprovada a anencefalia ou quando o feto padecer de graves e incuráveis anomalias que inviabilizem a vida extra-uterina, em ambos os casos atestado por dois médicos; ou IV - se por vontade da gestante, até a décima segunda semana da gestação, quando o 
ainda marcadas pela visão de controle sexual da mulher) ${ }^{59}$ Isso demonstra, em alguma medida, que o Legislativo não está alheio à discussão.

Nesse momento, atinge-se um ponto que é representativo das questões mais emblemáticas das democracias constitucionais: quem, legitimamente, têm a "última palavra" sobre o significado da Constituição? Legisladores democraticamente eleitos ou juízes não sujeitos a maiorias ocasionais (e, assim, supostamente imparciais)?

Sabe-se que esse debate parece já ter alcançado uma fase de exaustão argumentativa, sobretudo pela contínua reprodução das mesmas dúvidas e dos mesmos argumentos para respondê-las e, ainda assim, o impasse quanto à legitimidade da revisão judicial segue no centro da teoria constitucional, suscitando intermináveis e intensas divergências. A razão para tanto é que o Estado e o Direito precisam dessa definição quanto à "última autoridade democrática", pois disso depende a identificação do "soberano interno" que levará à ordem e à estabilidade almejadas. ${ }^{60}$

Por uma série de fatores, como a amplitude do texto constitucional, o sistema híbrido de controle de constitucionalidade e, notadamente, a crise de representatividade instaurada sobre os poderes majoritários, apenas para citar os mais flagrantes, não parece restar dúvidas de que, no cenário brasileiro hodierno, essa "autoridade final" encontra-se no Supremo Tribunal Federal. ${ }^{61}$

médico ou psicólogo constatar que a mulher não apresenta condições psicológicas de arcar com a maternidade. Paragrafo único. Nos casos dos incisos II e III e da segunda parte do inciso I deste artigo, o aborto deve ser precedido de consentimento da gestante, ou, quando menor, incapaz ou impossibilitada de consentir, de seu representante legal, do cônjuge ou de seu companheiro". Disponível em:

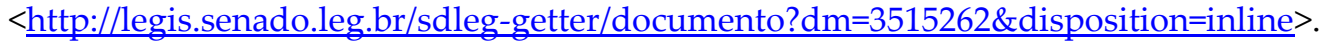
Acesso em: 29 de janeiro de 2018.

${ }^{59}$ Cf. DIAS, Fábio Freitas; DIAS, Felipe da Veiga. O aborto sob o viés constitucionalpenal da proporcionalidade e do bem jurídico: uma análise comparativa com a posição alemã e as novas propostas no Brasil. Revista da Ajuris, Vol. 41, 134, 2014.

${ }^{60}$ MENDES, Conrado Hübner. Is it All about the Last Word? Deliberative Separation of Powers. Legisprudence: International Journal for the Study of Legislation, Vol. 3, 1, 2009 , p. 69.

${ }^{61} \mathrm{O}$ que é sintomático de todo um contexto mais profundo de crise funcional do Estado, que além da perda de centralidade e exclusividade por conta de fenômenos como a globalização, ainda precisa enfrentar, internamente, um abalo na sua própria funcionalidade, comprometida em razão de tantas outras dimensões de crise 
Apesar da relevância desses fatores que decorrem de circunstâncias "externas" à Corte, no sentido de que conformam o próprio contexto em que se dará a atuação jurisdicional, é preciso reconhecer a insuficiência dessa narrativa para justificar, por si só, o enorme poder político que o Judiciário tem exercido. Embora o desenho institucional e até mesmo as expectativas sociais sejam "condições importantes [...] para um cenário em que o tribunal participa intensamente do processo político decisório nacional, não parecem ser condições suficientes para determinar o grau exato dessa participação em um dado momento". Isso é, "a construção da participação do STF no processo político-decisório no Brasil não pode ser plenamente explicada apenas com fatores exógenos à composição do STF", mesmo porque essa leitura ignora um aspecto absolutamente imprescindível: “[...] se e como as preferências dos Ministros do STF sobre como exercer o poder que dispõem - e inclusive sobre de quanto deveriam dispor - interagem com as já mencionadas variáveis exógenas [...]" para, aí sim, buscar explicações razoáveis quanto à intensificação do fenômeno da judicialização das últimas décadas. O que não se sustenta, pelo menos não mais, é a visão dos Ministros do Supremo como "vítimas", "reféns" ou meros espectadores de circunstâncias contextuais, quando são, em verdade, agentes do processo de construção e transformação do próprio poder do tribunal. ${ }^{62}$

Que "o Supremo é o resultado de sua ação e omissão, presença e ausência [...]", pode ser facilmente observado em pelo menos duas situações: "primeiro, sua agenda postergada, invisível, é tão importante quanto sua agenda formalizada e visível". ${ }^{63}$

No exercício do chamado poder de agenda, inclusive, é que se consegue demonstrar de forma concreta o quanto a determinação da extensão do poder em questão está, em muitos casos, na dependência

(financeira, ideológica, filosófica, estrutural, etc.). Essa "sacralização" da jurisdição constitucional é, em última análise, "[...] uma consequência inescapável a um Estado que se apresenta como de bem-estar, mas que se executa como de mal-estar [...]"

BOLZAN DE MORAIS, José Luis. As Crises do Estado e da Constituição e a

Transformação Espaço-Temporal dos Direitos Humanos. $2^{\underline{a}}$ ed. Porto Alegre, RS: Livraria do Advogado, 2012, p. 56-60.

${ }^{62}$ ARGUELHES, Diego Werneck. Poder não é querer: preferências restritivas e redesenho institucional no Supremo Tribunal Federal pós-democratização. In: Daniel Sarmento (Org.). Jurisdição Constitucional e Política. Rio de Janeiro, RJ: Forense, 2015, p. 213.

${ }^{63}$ FALCÃO, Joaquim; ARGUELHES, Diego Werneck. Onze Supremos: todos contra o Plenário. In: Joaquim Falcão, Diego Werneck Arguelhes e Felipe Recondo (Orgs.).

Onze Supremos: o Supremo em 2016. Belo Horizonte, MG: Letramento, 2017, p. 20. 
única e exclusiva dos próprios ministros. Com exceção de algumas prioridades decorrentes da legislação processual e do Regimento Interno do Supremo Tribunal Federal (dispondo apenas sobre prioridades de julgamento), não existem dispositivos que determinem, de modo claro e expresso, o trajeto a ser percorrido para a formação da pauta no Tribunal. Tanto a Constituição quanto a legislação ou o regimento não estabelecem “[...] requisitos ou critérios objetivos para inclusão do processo em pauta, seja na da Turma, do Plenário ou na pauta de decisões monocráticas do ministro relator". ${ }^{64}$

Com efeito, a "manipulação do tempo" acaba revelando um comportamento estratégico dos ministros, que, por essa via, podem alterar a trajetória dos processos, acelerando ou retardando a apreciação de determinadas matérias, fazendo com que algumas decisões sejam tomadas de modo muito mais lento do que outras ou, igualmente, que sejam tomadas de modo muito mais rápido ${ }^{65}$ - situações que ocorreram à exaustão nos últimos meses, em que o Supremo foi acionado diversas vezes para resolver problemas que impactavam diretamente nos rumos políticos do país.

Outra consideração que toca "o tempo" da decisão concerne ao "quando" decidir, sobretudo porque, nas democracias constitucionais, nenhum poder tem exclusividade para decidir sobre os direitos. A distribuição de funções estatais - consagrada como separação de poderes - acaba originando um intrincado circuito decisório do qual participam os diferentes poderes, cada um circunscrito a determinadas competências e a momentos específicos de intervenção. Ordinariamente, ao Legislativo competem as movimentações inaugurais desse circuito, resolvendo uma questão coletiva por meio de um estatuto geral e, assim, iniciando as inovações na ordem jurídica. Posteriormente, caso seja colocada em dúvida a validade constitucional de tal estatuto, os tribunais podem ser provocados a revisá-lo. Com efeito, nota-se que a dinâmica esperada de

${ }^{64}$ LIMA, Flavia Danielle Santiago; GOMES NETO, Jose Mario Wanderley. Poder de Agenda e Estratégia no STF: uma análise a partir da decisão liminar nos Mandados de Segurança nº 34.070 e no 34.071. In: Argemiro Cardoso Moreira Martins, Grasiele Augusta Ferreira Nascimento e Paulo Roberto Barbosa Ramos. (Orgs.). Constituição e Democracia II. Florianópolis, SC: CONPEDI, 2016, p. 11.

${ }^{65}$ LIMA, Flavia Danielle Santiago; GOMES NETO, Jose Mario Wanderley. Poder de Agenda e Estratégia no STF: uma análise a partir da decisão liminar nos Mandados de Segurança n⿳o 34.070 e no 34.071. In: Argemiro Cardoso Moreira Martins, Grasiele Augusta Ferreira Nascimento e Paulo Roberto Barbosa Ramos. (Orgs.). Constituição e Democracia II. Florianópolis, SC: CONPEDI, 2016, p. 14. 
períodos de normalidade político-constitucional faz com que o Judiciário seja reativo. ${ }^{66}$

Não se trata de uma posição reativa meramente por conta da necessidade de provocação da jurisdição, mas, especialmente, porque aos tribunais compete um papel de revisão, de verificação de adequação de leis e atos ao texto constitucional, assegurando, assim, que nenhuma previsão infraconstitucional que lhe seja contrária subsista no ordenamento jurídico.

Além disso, afastando-se dos fundamentos que idealizam esse papel da revisão judicial e, assim, eximindo os tribunais da responsabilidade de salvar a democracia dos perigos da política e do papel messiânico quanto à proteção dos direitos fundamentais, é possível perceber com maior clareza o arranjo institucional brasileiro estabelecido pela Constituição de 1988 e os seus problemas. No atual sistema constitucional, "uma adesão unânime à justificativa idealista do controle de constitucionalidade conduziu-o ao paroxismo" e por uma razão bastante evidente: a opção pela revisão judicial atrelada à validade moral das cláusulas pétreas sujeita àquele controle tanto o legislador ordinário quanto o reformador. Assim, desenha-se "um sistema no qual o circuito decisório termina na instituição desprovida do lastro de representatividade, dotada da capacidade de vetar, não de estatuir" 67 , o que é ainda mais alarmante.

Desse tipo de justificativa que eleva a jurisdição à condição quase sagrada de guardião constitucional, derivam as teorias de "última palavra", conferindo aos tribunais uma espécie de "direito de errar por último", atuando corretivamente sobre as instâncias representativas. A questão chave, contudo, é "o erro da instituição majoritária pode insuflar maior responsabilidade coletiva do que o erro de uma instituição não representativa, e a oportunidade de errar é inerente ao autogoverno democrático". ${ }^{68}$

A constante abdicação da tomada de decisões sobre questões morais relevantes em favor de instâncias judiciais que deveriam atuar reativamente e ao final do circuito decisório suprime a autonomia do povo, retirando-lhe a oportunidade de errar, ou mesmo de acertar. Quanto mais se restringe "a possibilidade de atuar autonomamente,

${ }^{66}$ MENDES, Conrado Hübner. Is it All about the Last Word? Deliberative Separation of Powers. Legisprudence: International Journal for the Study of Legislation, Vol. 3, 1, 2009, p. 72-73.

${ }^{67}$ MENDES, Conrado Hübner. Direitos Fundamentais, Separação de Poderes e Deliberação. São Paulo, SP: Saraiva, 2011, p. 27-28.

${ }^{68}$ MENDES, Conrado Hübner. Direitos Fundamentais, Separação de Poderes e Deliberação. São Paulo, SP: Saraiva, 2011, p. 28.

3 JOURNAL OF INSTITUTIONAL STUDIES 2 (2017) 
atribuindo decisões fundamentais a guardiões, menor será a possibilidade de desenvolver um senso de responsabilidade pelas ações coletivas", do que decorre "uma infantilização paternalista do povo" ${ }^{69}$

Tal é o cenário em que Maus vai identificar "o judiciário como superego da sociedade", no qual "a eliminação de discussões e procedimentos no processo de construção política do consenso [...] é alcançada através da centralização da 'consciência' social na justiça". ${ }^{70}$

Aliando essas constatações ao julgamento do HC 124.306/RJ, ponto de partida concreto da investigação proposta porque, justamente, sintomático e representativo do que tem sido a atuação da jurisdição constitucional pela Suprema Corte brasileira, há, ainda, outro problema observável, que diz respeito à própria postura e ao comportamento dos julgadores enquanto Corte Constitucional. ${ }^{71}$

Isso porque o Supremo Tribunal Federal "resulta também da tensão entre sua ação institucional e o comportamento individual - quase sempre discricionário - de seus ministros" ${ }^{72}$ Não se pode perder de vista que a Constituição atribui poderes e competências ao Tribunal, sem previsão de poder decisório aos ministros individualmente considerados e, ainda assim, as decisões judiciais mais importantes do ano de 2016 derivam de atuações isoladas, sem a participação do plenário. ${ }^{73}$

Essa assertiva, importante sublinhar, vai além de uma percepção

${ }^{69}$ MENDES, Conrado Hübner. Direitos Fundamentais, Separação de Poderes e Deliberação. São Paulo, SP: Saraiva, 2011, p. 29.

${ }^{70}$ MAUS, Ingeborg. O Judiciário como Superego da Sociedade: sobre o Papel da Atividade Jurisprudencial na "Sociedade Órfã". Trad. Martonio Mont'Alverne Barreto Lima e Paulo Menezes Albuquerque. Novos Estudos - CEBRAP, No. 58, 2000, p. 128.

${ }^{71}$ STF, HC 124.306/RJ, Voto Vista, Min. Roberto Barroso, Proferido em 29/11/2016.

Disponível em:

$<$ http://www.stf.jus.br/arquivo/cms/noticiaNoticiaStf/anexo/HC124306LRB.pdf $>$. Acesso em: 12 de janeiro de 2017.

72 “Nos dois níveis, observamos uma dinâmica similar: o plenário é sitiado de todos os lados pela ação individual de ministros. Positivamente, atuam para decidir temas que consideram, mas fora do controle do plenário. Negativamente, atuam na formação da agenda, para evitar que certos temas sejam objeto de qualquer decisão" FALCÃO, Joaquim; ARGUELHES, Diego Werneck. Onze Supremos: todos contra o Plenário. In: Joaquim Falcão, Diego Werneck Arguelhes e Felipe Recondo (Orgs.). Onze Supremos: o Supremo em 2016. Belo Horizonte, MG: Letramento, 2017, p. 20.

${ }^{73}$ FALCÃO, Joaquim; ARGUELHES, Diego Werneck. Onze Supremos: todos contra o Plenário. In: Joaquim Falcão, Diego Werneck Arguelhes e Felipe Recondo (Orgs.).

Onze Supremos: o Supremo em 2016. Belo Horizonte, MG: Letramento, 2017, p. 20. 
ocasional, pois pode ser comprovada em termos quantitativos. Os dados do projeto "Supremo em Número" (FGV Direito Rio) revelam que "decisões nas quais há múltiplos ministros envolvidos são excepcionais, e respondem por uma ínfima parte do tempo e da estrutura do Tribunal". Precisamente, "em todos os tipos de processos julgados pelo Tribunal, o percentual médio de decisões monocráticas entre 1992 e 2013 fica em $93 \% " .{ }^{74} \mathrm{Ou}$ seja, enquanto as decisões colegiadas são a exceção, as decisões monocráticas tornaram-se a regra.

Isso indica que, a partir do controle que exercem sobre o destino dos autos dos processos, os ministros investem-se, individualmente, de um poder que é institucional. Ao invés de levar as "teses para disputa de seus colegas, no confronto democraticamente controlado do colegiado", o julgador faz valer, monocraticamente, a sua tese. ${ }^{75}$

Dentre todos os problemas democráticos que essa "diminuição" do colegiado da Corte suscita, assinala-se que "a decisão individual toma emprestado o poder e a responsabilidade institucionais para fazer valer uma escolha do ministro que, às vezes, não sobreviveria à influencia moderadora do plenário". ${ }^{76} \mathrm{Ou}$ seja, o poder decisório individual chegou a tal ponto que pode, facilmente, evitar, constranger ou mesmo contrariar o plenário.

No caso do julgamento do HC 124.306/RJ pela Primeira Turma do Supremo Tribunal Federal, foram os votos de três ministros (Luís Roberto Barroso, Rosa Weber e Edson Fachin) que decidiram que a prática de aborto até o terceiro mês de gestação não pode ser considerada crime, dada a inconstitucionalidade do tipo penal em questão (os outros dois ministros que compõem esta Turma, Marco Aurélio e Luiz Fux, sequer se manifestaram sobre tal descriminalização). ${ }^{77}$

Ainda que não seja uma decisão vinculante e que não expresse a

${ }^{74}$ Cf. ARGUELHES, Diego Werneck; HARTMANN, Ivar. A monocratização do STF. Jota, 03/08/2015. Disponível em: $<$ https://jota.info/artigos/a-monocratizacao-do-stf03082015>. Acesso em: 29 de janeiro de 2018.

${ }^{75}$ FALCÃO, Joaquim; ARGUELHES, Diego Werneck. Onze Supremos: todos contra o Plenário. In: Joaquim Falcão, Diego Werneck Arguelhes e Felipe Recondo (Orgs.).

Onze Supremos: o Supremo em 2016. Belo Horizonte, MG: Letramento, 2017, p. 21-22.

${ }^{76}$ FALCÃO, Joaquim; ARGUELHES, Diego Werneck. Onze Supremos: todos contra o Plenário. In: Joaquim Falcão, Diego Werneck Arguelhes e Felipe Recondo (Orgs.).

Onze Supremos: o Supremo em 2016. Belo Horizonte, MG: Letramento, 2017, p. 25. 77 STF, HC 124.306/RJ, Voto Vista, Min. Roberto Barroso, Proferido em 29/11/2016.

Disponível em:

$<$ http://www.stf.jus.br/arquivo/cms/noticiaNoticiaStf/anexo/HC124306LRB.pdf $>$. Acesso em: 12 de janeiro de 2017. 
posição do Supremo Tribunal Federal enquanto Corte Constitucional, as notícias recorrentes anunciam que "o Supremo autorizou o aborto". Não se pode ignorar o impacto de uma decisão como essa para o futuro posicionamento do Tribunal, que tem pela frente o julgamento da ADI 5.581, por exemplo. Pode-se projetar, a partir disso, que de agora em diante, eventual decisão do plenário no sentido de desautorizar o aborto soe como uma contradição ou como um retrocesso, pois a decisão do HC 124.306/RJ, mesmo emanada de julgadores específicos, reveste-se, como dito, das prerrogativas e poderes institucionais exercidos pelos ministros naquele momento. ${ }^{78}$

Sabe-se que, no Brasil, a discussão sobre temas delicados, como no caso do aborto, encontra uma série de barreiras políticas, sociais e morais que, se analisadas a fundo, possivelmente não se sustenta e, com toda a certeza, não justifica a manutenção de um tipo penal que, a pretexto de proteger a vida, causa tantas mortes.

Contudo, em uma democracia, para auferir a legitimidade de uma decisão, a forma e o procedimento importam tanto quanto o conteúdo do que se decide ${ }^{79}$, pois, acima de quaisquer disputas entre poderes (que

${ }^{78}$ STF, HC 124.306/RJ, Voto Vista, Min. Roberto Barroso, Proferido em 29/11/2016.

Disponível em:

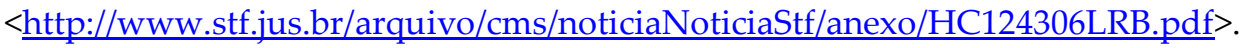

Acesso em: 12 de janeiro de 2017.

${ }^{79}$ Sobre o "como decidir": "You decide how? This designates the steps that are necessary to take a valid and legitimate decision. It is concerned with the fairness of the procedure that the members of the community have chosen to decide their common concerns. The legitimacy of a decision in a constitutional democracy is measured both for its content and for its procedure. With respect to questions that provoke a high level of disagreement, as it happens with conflicts of rights, the procedural dimension appears even more strikingly than one of the crucial choices to be made. The recognition of a fair procedure would encourage compliance with the non-consensual outcomes. The first procedural choice made by contemporary constitutional regimes was to dilute power so that, through checks and balances, it prevents arbitrary violations of rights. But there are further steps that go beyond simply dividing power. The second procedural choice, in a supplementary level, was to reflect upon the legitimate role of each branch. Legislatures, according to conventional description, are responsible for instantiating the principle of majority rule and the electoral representation of the people. Courts, in turn, are insulated from electoral politics in order to have ideal conditions of impartiality and to decide upon rights, which can not, by definition, be subject to the majoritarian kind of justification. It is also expected that within courts the decisions are driven, first of all, by argument 
deveriam atuar harmonicamente), deve prevalecer o texto constitucional. Se já é um ponto sensível à democracia constitucional, a definição de "quem detém o poder da última palavra" quanto à interpretação da extensão e do sentido da Constituição, isso é, se já há relutância e controvérsia quanto à atribuição dessa missão a Cortes, muito mais grave é a afronta quando, a despeito dessas considerações, a "última palavra" vem sendo ditada unilateralmente.

\section{ConClusão}

O presente trabalho propôs-se a investigar a atuação do Supremo Tribunal Federal no julgamento do Habeas Corpus 124.306/RJ, buscando a compreensão não apenas dos parâmetros dessa decisão, especificamente, mas também do que, a partir daí, poderia ser apreendido em termos de exercício da jurisdição constitucional. ${ }^{80}$

De uma averiguação minuciosa acerca dos aspectos formais e materiais da decisão central da pesquisa, fez-se um comparativo com outros posicionamentos da Corte em situações semelhantes, objetivando diagnosticar o modus operandi do exercício da jurisdição constitucional pelo Supremo e as implicações democráticas dessa atuação.

As buscas e o estudo sistemático dos resultados encontrados apontaram que: i) a apreciação do mérito da causa não raras vezes encontra-se diretamente ligada às possibilidades dos diferentes mecanismos processuais, de modo que o debate sobre a via adequada

and deliberation, whereas legislatures are more subject to bargaining, aggregation of preferences and voting, since this decisional place would be more refractory to deliberation. Apart from these considerations of pure procedural inputs, however, the dimension of 'how' also touches the formal qualities of the different outputs that courts and legislatures produces. Courts take decisions that have a particular incremental, both forward and backward-looking rationality, as opposed to legislation, which usually corresponds to a prospective and general rule. Regardless of the output content, therefore, the formal qualities of the output are inherent to the procedural design of these institutions". MENDES, Conrado Hübner. Is it All about the Last Word? Deliberative Separation of Powers. Legisprudence: International Journal for the Study of Legislation, Vol. 3, 1, 2009, p. 72.

${ }^{80}$ STF, HC 124.306/RJ, Voto Vista, Min. Roberto Barroso, Proferido em 29/11/2016.

Disponível em:

$<$ http://www.stf.jus.br/arquivo/cms/noticiaNoticiaStf/anexo/HC124306LRB.pdf $>$. Acesso em: 12 de janeiro de 2017. 
para o procedimento reveste-se de tanta importância quanto o conteúdo do que deve ser decidido (o que, em verdade, é ínsito à própria democracia); ii) embora sedimentado na jurisprudência da Corte o entendimento pela não admissão de habeas em substituição ao recurso ordinário, flexibiliza-se essa posição quando está presente a condição de cerceamento da liberdade do paciente; iii) ainda assim, não foi possível identificar um padrão de decisão, ou melhor, em casos bastante pontuais, encontrou-se um desvio na forma de justificar os votos do ministro Luís Roberto Barroso, voltando-se para a relevância da matéria sob a perspectiva de afetação a direitos fundamentais (ainda que a decisão implique em contrariar jurisprudência firmada, como no caso do Habeas Corpus 124.306/RJ'

Ainda com relação à decisão de mérito do referido habeas corpus, restou evidenciado que, a despeito de toda a relevância do assunto, não se estava diante do momento e do espaço adequados para a discussão de eventual inconstitucionalidade do tipo penal do aborto, tendo em vista, dentre outros fatores, que o remédio constitucional em questão não serviria a tal finalidade e sequer contemplava qualquer pedido nesse sentido.

Com efeito, os casos examinados acabam por confirmar uma certa falta de controle e de parâmetros claros no exercício da jurisdição constitucional justamente pelo Tribunal diretamente encarregado pela guarda da Constituição na missão de assegurar-lhe a efetividade. Se, por um lado, essa tendência de protagonismo do judiciário (e o que é ainda mais grave, de juízes), sobretudo no que concerne à intepretação e aplicação do texto constitucional, é parte de um contexto muito mais amplo, formado por um conjunto de determinações institucionais, por outro, a ameaça democrática que aí se encerra não se torna menos preocupante por conta disso.

\section{REFERÊNCIAS}

ALEXY, Robert. Teoria dos Direitos Fundamentais. Trad. Virgílio Afonso da Silva. São Paulo, SP: Malheiros, 2008.

${ }^{81}$ STF, HC 124.306/RJ, Voto Vista, Min. Roberto Barroso, Proferido em 29/11/2016.

Disponível em:

$<$ http://www.stf.jus.br/arquivo/cms/noticiaNoticiaStf/anexo/HC124306LRB.pdf $>$. Acesso em: 12 de janeiro de 2017.

3 JOURNAL OF INSTITUTIONAL STUDIES 2 (2017) 
ALIMENA, Carla Marrone. A tentativa do (im)possível: feminismos e criminologias. Rio de Janeiro, RJ: Lumen Juris, 2011.

ARGUELHES, Diego Werneck. Poder não é querer: preferências restritivas e redesenho institucional no Supremo Tribunal Federal pósdemocratização. In: Daniel Sarmento (Org.). Jurisdição Constitucional e Política. Rio de Janeiro, RJ: Forense, 2015.

ARGUELHES, Diego Werneck; HARTMANN, Ivar. A monocratização do STF. Jota, 03/08/2015. Disponível em: $<$ https://jota.info/artigos/amonocratizacao-do-stf-03082015>. Acesso em: 29 de janeiro de 2018.

BOLZAN DE MORAIS, José Luis. As Crises do Estado e da Constituição e a Transformação Espaço-Temporal dos Direitos Humanos. $2^{\underline{a}}$ ed. Porto Alegre, RS: Livraria do Advogado, 2012.

DIAS, Fábio Freitas; DIAS, Felipe da Veiga. O aborto sob o viés constitucional-penal da proporcionalidade e do bem jurídico: uma análise comparativa com a posição alemã e as novas propostas no Brasil. Revista da Ajuris, Vol. 41, 134, 2014.

FALCÃO, Joaquim; ARGUELHES, Diego Werneck. Onze Supremos: todos contra o Plenário. In: Joaquim Falcão, Diego Werneck Arguelhes e Felipe Recondo (Orgs.). Onze Supremos: o Supremo em 2016. Belo Horizonte, MG: Letramento, 2017.

GLOECKNER, Ricardo Jacobsen. Risco e Processo Penal: uma análise a partir dos Direitos Fundamentais do Acusado. Salvador, BA:

JusPodivm, 2009.

LIMA, Flavia Danielle Santiago; GOMES NETO, Jose Mario Wanderley. Poder de Agenda e Estratégia no STF: uma análise a partir da decisão liminar nos Mandados de Segurança no 34.070 e no 34.071. In: Argemiro 
Cardoso Moreira Martins, Grasiele Augusta Ferreira Nascimento e Paulo Roberto Barbosa Ramos. (Orgs.). Constituição e Democracia II. Florianópolis, SC: CONPEDI, 2016.

LOPES JÚNIOR, Aury. Direito Processual Penal. 11ª ed. São Paulo, SP: Saraiva, 2014.

MAUS, Ingeborg. O Judiciário como Superego da Sociedade: sobre o Papel da Atividade Jurisprudencial na "Sociedade Órfã". Trad. Martonio Mont'Alverne Barreto Lima e Paulo Menezes Albuquerque. Novos Estudos - CEBRAP, No. 58, 2000.

MENDES, Conrado Hübner. Direitos Fundamentais, Separação de Poderes e Deliberação. São Paulo, SP: Saraiva, 2011.

. Is it All about the Last Word? Deliberative Separation of Powers. Legisprudence: International Journal for the Study of Legislation, Vol. 3, 1, 2009.

ORGANIZAÇÃO DAS NAÇÕES UNIDAS. Draft report of the Working Group on the Universal Periodic Review: Brazil. Geneva: ONU, 2017. Disponível em: $<$ http://acnudh.org/wpcontent/uploads/2017/05/A HRC WG.6 27 L.9 Brazil.pdf>. Acesso em: 29 de janeiro 2018.

ORGANIZAÇÃO MUNDIAL DA SAÚDE. Mulheres e Saúde: evidências de hoje, agenda de amanhã. Trad. Jean-Pierre Barakat. Genebra: WHO Press, 2011, p. 42-43. Disponível em: $<$ http://www.who.int/eportuguese/publications/Mulheres Saude.pdf?ua =1>. Acesso em: 14 de maio de 2017.

PIOVESAN, Flávia. Direitos Sexuais e Reprodutivos: Aborto Inseguro como Violação aos Direitos Humanos. In: Daniel Sarmento e Flávia Piovesan (Org.). Nos Limites da Vida: Aborto, Clonagem Humana e 
Eutanásia sob a perspectiva dos Direitos Humanos. Rio de Janeiro, RJ: Lumen Juris, 2007.

SÁNCHEZ RUBIO, David; SENENT DE FRUTOS, Juan Antonio. Teoría Crítica del Derecho: Nuevos Horizontes. Sevilla: Centro de Estudios Jurídicos y Sociales Mispat, 2013.

SARMENTO, Daniel. Legalização do Aborto e Constituição. Alcilene Cavalvante e Dulce Xavier (Orgs.). Em Defesa da Vida: Aborto e Direitos Humanos. São Paulo, SP: Católicas pelo Direito de Decidir, 2006.

WAMBIER, Teresa Arruda Alvim. O óbvio que não se vê: a nova forma do Princípio da Fungibilidade. Argumenta Journal Law, No. 6, 2006.

Jurisdição Constitucional e a Questão do Aborto a partir do HC 124.306/RJ Judicial Review and the Question of Abortion from HC 124.306/RJ

Submetido em: 2017-10-11

Aceito em: 2018-02-04 